\title{
Retraction Note to: Search of Self Amidst Chaos
}

\author{
Pankaj Suneja
}

Published online: 8 December 2020

(C) Springer Nature India Private Limited 2020

Retraction Note to: J. Psychosoc. Rehabil. Ment. Health (2015) 2(1):97-99 https://doi.org/10.1007/ s40737-015-0023-8

The Editor-in-Chief has retracted this article [1] at the request of the author. The article had been submitted by the author, underwent peer review as per the Journals' procedures, and was published in 2015. To respect the privacy of the author the content of the article is no longer available online.

\section{Reference}

1. Suneja P. Search of self amidst chaos. J Psychosoc Rehabil Ment Health. 2015;2:97-9.

Publisher's Note Springer Nature remains neutral with regard to jurisdictional claims in published maps and institutional affiliations.
The original article can be found online at https:// doi.org/10.1007/s40737-015-0023-8.

P. Suneja $(\bowtie)$

New Delhi 110085, India

e-mail: outofthecave6@yahoo.in 